\title{
The Future Of Accounting Profession in The Industrial Revolution 4.0: Meta- Synthesis Analysis
}

\author{
Ni Made Kariana Rosi ${ }^{1}$ \\ Fakultas Ekonomi dan Bisnis \\ Universitas Pendidikan Nasional, \\ Indonesia
}

Luh Putu Mahyuni ${ }^{2}$

Fakultas Ekonomi dan Bisnis

Universitas Pendidikan Nasional,

Indonesia

\begin{abstract}
Surel : karianarosi98@gmail.com
ABSTRACT

Various appearances of applied technology, such as Artificial Intelligence (AI), Internet of Things (IoT), and Big Data are all Industrial Revolution 4.0 characteristics that can change the business model. This research aims to explore how the advancement of Industrial Revolution 4.0 technology might disrupt the accounting profession. This research applied metasynthesis method. The results of this study illustrated that the importance of development in the accounting sector is to keep pace with technological advances in industry 4.0. This must be balanced with the development of knowledge in the field of accounting so that all types of development can be carried out as well as possible. The findings showed that the appearance of various kinds new technology had a very significant impact in the development of the accounting profession. Further research should be able to discuss the Industrial Revolution 4.0 impact in more depth and can be linked to other accounting professions, such as internal auditors.
\end{abstract}

Keywords: Accounting Profession; Industrial Revolution 4.0; Technology.

\section{Masa Depan Profesi Akuntansi Dalam Revolusi Industri 4.0: Analisis Meta-Sintesis}

\begin{abstract}
ABSTRAK
Berbagai kemunculan teknologi terapan, seperti Artificial Intelligence (AI), Internet of Things (IoT), dan Big Data merupakan ciri-ciri Industrial Revolution 4.0 yang dapat mengubah model bisnis. Penelitian ini bertujuan untuk mengetahui bagaimana kemajuan teknologi Revolusi Industri 4.0 dapat mengganggu profesi akuntan. Penelitian ini menggunakan metode meta-sintesis. Hasil penelitian ini menggambarkan bahwa pentingnya pembangunan di bidang akuntansi adalah untuk mengimbangi kemajuan teknologi di industri 4.0. Hal tersebut harus diimbangi dengan perkembangan pengetahuan di bidang akuntansi agar segala jenis pengembangan dapat terlaksana dengan sebaik-baiknya. Hasil penelitian menunjukkan bahwa kemunculan berbagai macam teknologi baru memberikan pengaruh yang sangat signifikan dalam perkembangan profesi akuntansi. Penelitian lebih lanjut harus dapat membahas dampak Revolusi Industri 4.0 secara lebih mendalam dan dapat dikaitkan dengan profesi akuntansi lainnya, seperti auditor internal.
\end{abstract}

Kata Kunci: $\quad$ Profesi Akuntansi; Revolusi Industri 4.0; Teknologi.

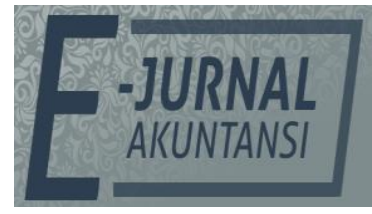

e-ISSN 2302-8556

Vol. 31 No. 4

Denpasar, April 2021

Hal. 1010-1024

DOI:

10.24843/EJA.2021.v31.i04.p17

PENGUTIPAN:

Rosi, N.M.K., \& Mahayuni, L.P. (2021). The Future Of Accounting Profession in

The Industrial Revolution 4.0: Meta-Synthesis Analysis. E-Jurnal Akuntansi, 31(4), 1010-1024

RIWAYAT ARTIKEL: Artikel Masuk: 6 Februari 2021 Artikel Diterima: 24 April 2021

Artikel dapat diakses : https://ojs.unud.ac.id/index.php/Akuntansi/index 


\section{INTRODUCTION}

Among the most important revolutions in human history, two of them are first the agricultural revolution and then the industrial revolutions. Until today, three important industries revolution have been experienced, and nowadays we are transitioning to a new industrial revolution that is mostly consisted of digital innovation, which is known as the industrial revolution 4.0, that creates a lot of innovations and developments, especially in the field of technology. Various appearances of applied technology, such as advanced robotics, artificial intelligence, internet of things, virtual and augmented reality, additive manufacturing, and distributed manufacturing are all characteristics of the Industrial Revolution 4.0. For example, at this time since the arrival of smartphones that have various functions such as Google search, it is very easy for people to find various things that are needed in daily life.

The development of information technology in the field of accounting in industrial revolution 4.0 has been going on massively as time goes by. The use of technology-based accounting has an impact on efficiency against time, effort, and cost. Besides, the enhancements are getting more and more effective in order to get accurate and precise financial report output as the trigger for the growing use of information technology in the field of accounting.

Some traditional jobs such as accountants will disappear as their profession loses its importance and does not need human personnel anymore because of digital applications Khanh (2018). In line with Khanh (2018); Wahyuni (2020) it is also argued that there is a shift in the role of accountants from bookkeepers to experts in providing financial data or as data analysts so that accountants must be able to understand technology to carry out future tasks.

The accounting profession can be replaced by robots because of the existence of accounting software that supports the work of accountants, making it easier for the accountant's professional activities, but it makes the human resources needed in business, including accounting staff, not many (Halmi, 2018). Therefore, many people worry that the accounting profession is no longer needed by the business world in the era of big data because it is being replaced by various accounting software that is cheaper, faster and more accurate in recording financial transactions.

According to the researcher, this is not entirely true because there has only been a shift in the role of accountants who previously worked on technical tasks of preparing financial statement transactions to provide support for corporate management decision-making processes such as identifying nonfinancial measurements, developing ways of quantifying unstructured data, determining the right time to. Make decisions, and estimate the impact of decisions on the financial results and operational performance of the company by using big data analysis, or in other words, accountants act as high-level decision support specialists Pratolo (2015).

It is expected that with the creation of increasingly rapid technological advances, it can provide good potential for an accountant in carrying out his/her activities. The study is still needed further to map in full how the advancement of Industrial Revolution 4.0 technology might disrupt the accounting profession. 


\section{RESEARCH METHODS}

This method of synthesizing (summarizing) the results of qualitative research was called "Meta-Synthesis". By definition, meta-synthesis is a technique to integrate data to obtain new theories or concepts or a deeper and more comprehensive level of understanding Perry \& Hammond (2002).

In the initial stage, in accordance with the researcher search protocol, the researcher was able to retrieve 80 articles from Google Scholar by using the keywords as follows: "Accounting Profession and Industrial Revolution 4.0", "The impact of industrial revolution 4.0 against the accounting profession", and "Accounting profession in 4.0 era." After the first screening, which was based on the titles of the journal, 31 articles were excluded, leaving 49 articles for further screening. The removed journals were not related to accounting profession in the industrial revolution 4.0. All 49 articles were then read thoroughly in order to precisely identify the similarities of the studies. After reading 49 articles there were 9 articles that must be excluded for not intensively discussing accounting profession in industrial revolution 4.0. At the end of the screening process, there were 40 articles selected for inclusion in the research.

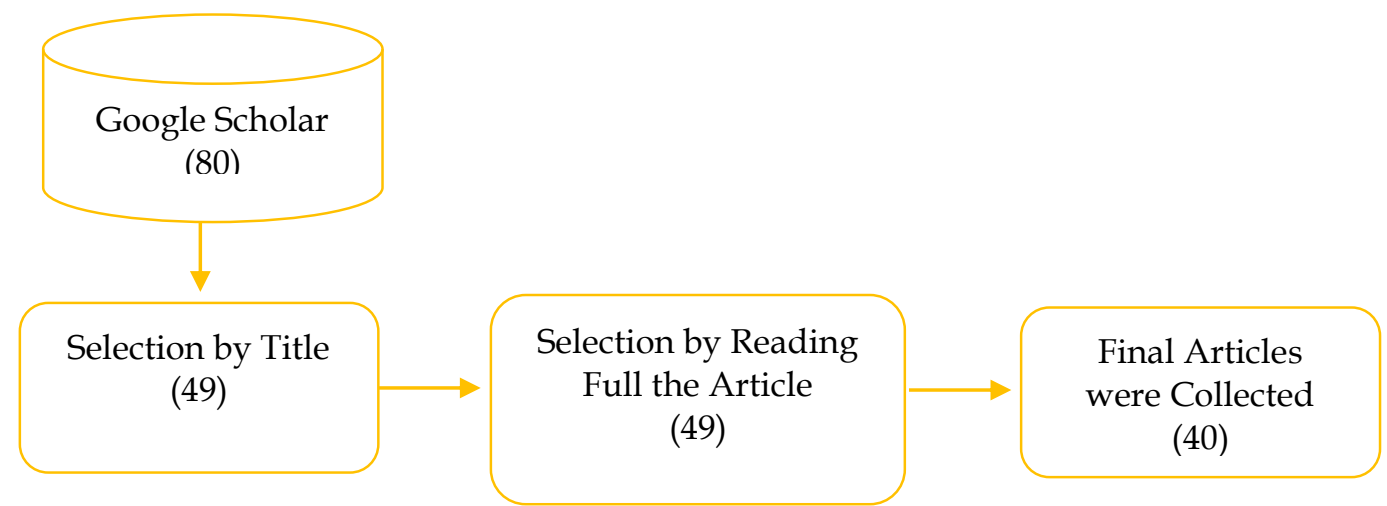

Figure 1. The Selection Process of Relevant Articles

Source: Research Data, 2020

Even though there was no year limit in searching for the articles, all selected articles were published from 2011 to 2020. Figure 2, shows the publication years of the articles, with the majority were published in 2019 (17 articles).

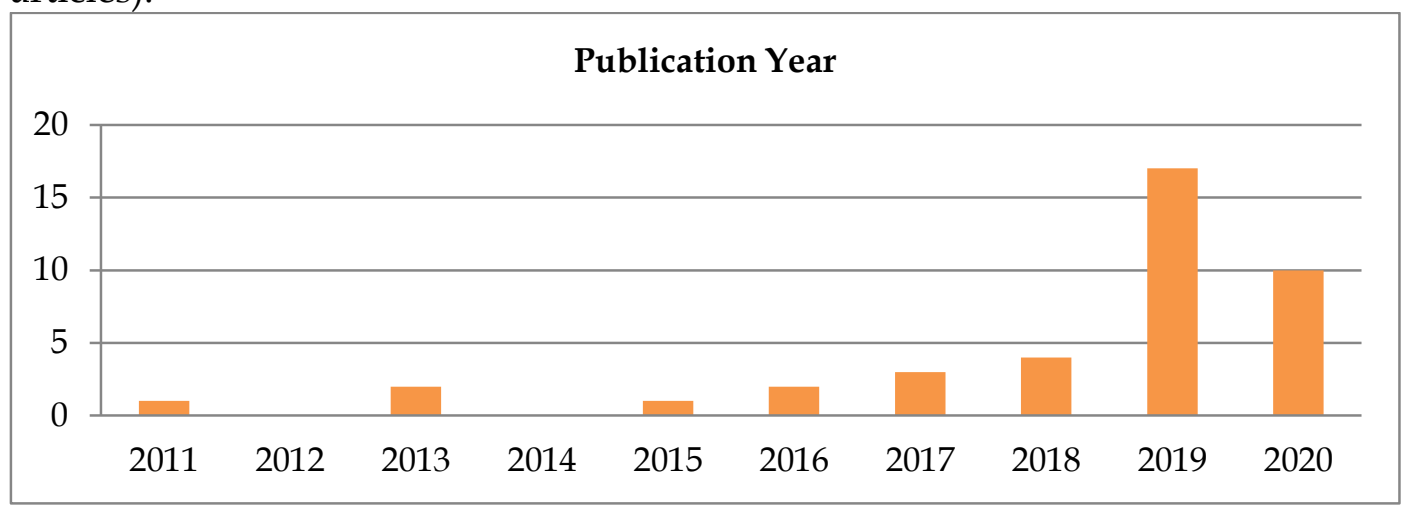

Figure 2. The Publication Years of the Articles

Source: Research Data, 2020 
To answer this research question, the articles material used in the metasynthesis process are grouped into themes and codes. The articles are read one by one to determine the theme and code to be used. After reading carefully, the themes and codes are found based on words that often appear in the articles. Figure 3, shows the results of mapping the themes and codes of 40 articles analyzed in this research.

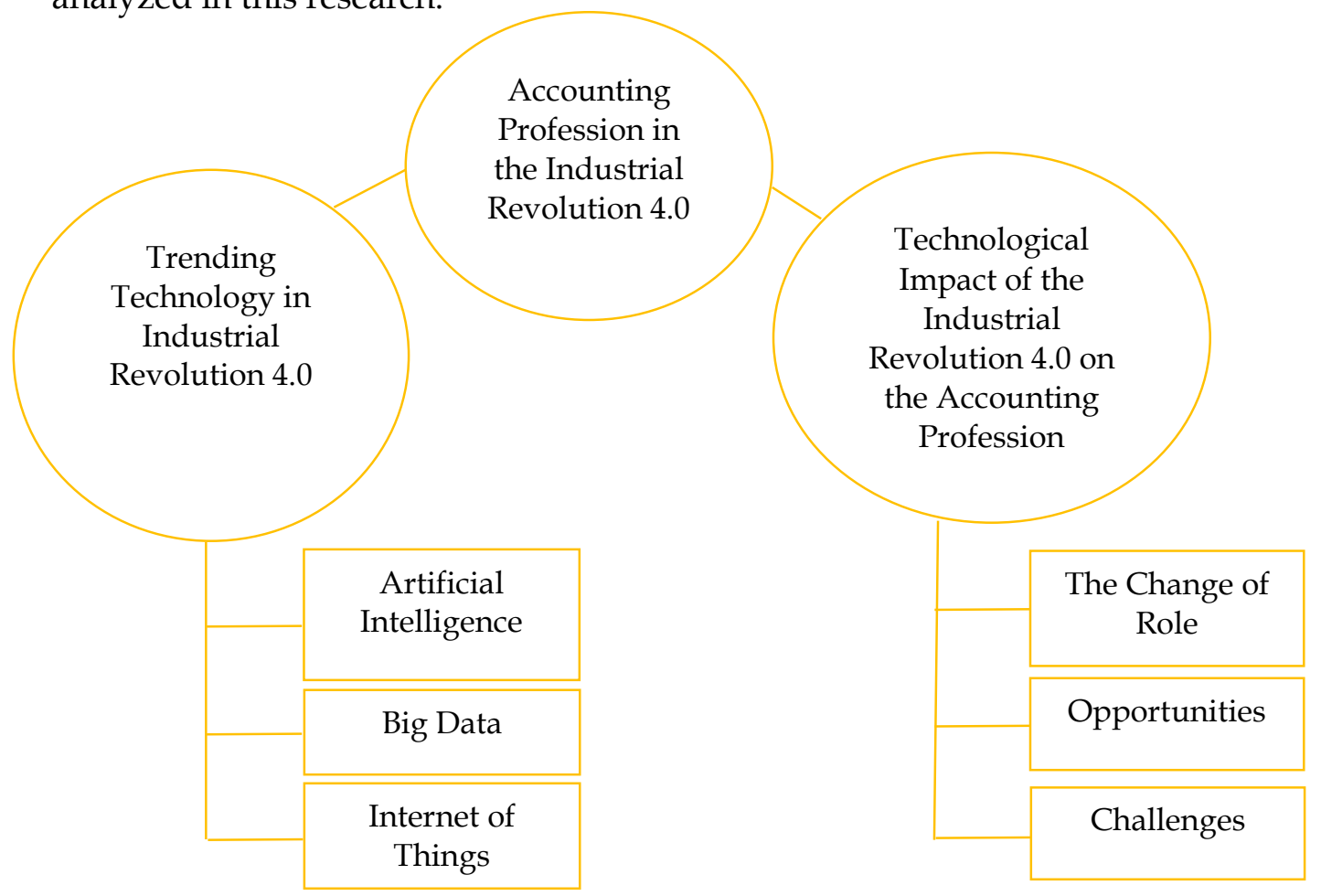

Figure 3. Mapping the Themes and Codes

Source: Research Data, 2020

After the articles were collected, mapping was carried out regarding the findings of the articles regarding the methods used and the conclusions presented in each journals, until finally achieving the goal of this study, namely to explore how technological advances in the Industrial Revolution 4.0 can disrupt the accounting profession.

\section{RESULTS AND DISCUSSION}

The industrial revolution that began in England more than two centuries ago, brought the world to the modernization we know today. This revolution has also created an economic order that has brought about fundamental changes to the strata of social life globally. The industrial revolution occurred following the times that demanded development in the industrial world that could help people in their daily life.

Industrial development has an influence on various sectors in various fields related to people's lives, one of which is in the economic field. One of the economic fields that affect people's lives is the very influential accounting sector.

The field of accounting affects all types of activities related to data, financial information, information systems, technology systems in data input and 
so on. The field of accounting is often directly related to people's lives because it contains a lot of information about people's economic activities.

Burritt \& Christ (2016a) in their research said that environmental accounting can help corporate sustainability in developing a vision and mission for the Industrial revolution 4.0. The results of this study provided an overview of how environmental accounting in the industrial era 4.0 can help develop companies. Company development in world industry 4.0 can increase the company's potential in viewing business opportunities on a large scale. Companies that can see great opportunities can consider the process of investing heavily in the investment market, thereby increasing the company's profits and development. According to Burritt \& Christ (2016b) there are four steps that accountants need to take in the face of the industrial revolution 4.0: 1) Awareness. The industrial revolution gave birth to new opportunities or opportunities. This opportunity is growing new businesses that never existed before. Hence, the example of Germany as the initiating country has $80 \%$ of companies ready to implement industrial revolution 4.0 or China that understands if development is needed on the knowledge factor and targets $60 \%$ investment in this field. It is obvious that it is not only these two countries but many countries are already in the initial step of disseminating information, which after that, will grow deeper to run with the whole revolution 4.0. 2) Education. Regulators or the government and education activists are required to be able to make a curriculum related to changes in digital connectivity, such as coding training, information management between several programs, and unequal basis or implementation of real-time accounting intended for all departments and company organizations as holders of stock. 3) Career Development. Increase the career capacity of accountants and programs that support their development by doing online presentation exercises or face-to-face discussions and assessing their effects on the career capabilities of accountants in the future. 4) Application of high standards. The accountant is required to have optimal control over the data created, where data or physical information is generally obtained under the responsibility of several engineers so that the fabric of work between the accountant and engineer must go hand in hand so that the data and accounting information are well maintained.

Several researchers (Stanceva-Todorova, 2019) and (Surianti, 2020) stated that the expected target of this research is to produce a curriculum design that can be used as input in the revision of the curriculum for the Public Financial Accounting Study Program and the Accounting Study Program which is planned to be implemented in 2020. From the results of the research, it is identified that there is a role of accountants, where this shift causes changes of hard skills and soft skills that an accountant must have. In addition, to accommodate the changes that occur two approaches can be used, namely by entering topics in existing subjects, or by creating new courses. Development of the curriculum has a very important influence in improving accounting skills that can help face industry 4.0. So that curriculum development can be carried out, and it can keep up with global progress especially in connection with the industrial revolution 4.0. (Gamage, 2016) stated that there are Some of the topics that can be integrated into the existing courses are given in Table 1. 
Table 1. The Topics That Can Be Integrated Into The Existing Courses

\begin{tabular}{|c|c|}
\hline Course & Topic \\
\hline Business Statistic & $\begin{array}{l}\text { Data Gathering techniques, data exploration, data } \\
\text { summarization, data analysis, data visualization, } \\
\text { communication of analytical findings. }\end{array}$ \\
\hline Business Information & Advanced database, information retrieval, advanced Data \\
\hline Management & $\begin{array}{l}\text { mining applications, predictive analytics for discussion } \\
\text { making, big data information management. }\end{array}$ \\
\hline Management Acoounting & $\begin{array}{l}\text { Application for big data to competitor analysis, big data as } \\
\text { a strategic resource }\end{array}$ \\
\hline $\begin{array}{l}\text { Accounting Information } \\
\text { System }\end{array}$ & $\begin{array}{l}\text { Business intelligence, enterprise analysis for search and } \\
\text { retrieval, data mining, familiarity with languages such as }\end{array}$ \\
\hline & $\begin{array}{l}\text { XBRL, specialized software/reporting systems with } \\
\text { decision support, ERP systems, Cybercrime, Data } \\
\text { Management issues. }\end{array}$ \\
\hline Business Finance & $\begin{array}{l}\text { Financial analytics, modelling and computation of } \\
\text { financial risk, information risk management }\end{array}$ \\
\hline Auditing and Assurance & $\begin{array}{l}\text { Data analytics in auditing, mine new sources of data, data } \\
\text { integrity, privacy, safeguards, cybersecurity, design and } \\
\text { evaluate is controls, manage is risk and compliance, } \\
\text { overseeing fraud risk assessment. }\end{array}$ \\
\hline \multirow[t]{2}{*}{ Forensic Accounting } & Big data, benford's law, financial analystics, Data \\
\hline & $\begin{array}{l}\text { Analytics for fraud, anomaly detection in forensics and } \\
\text { security }\end{array}$ \\
\hline Taxation & $\begin{array}{l}\text { Indirect tax and big data, tax value and non-tax value } \\
\text { from data that is collected in the tax function, visualize } \\
\text { accounting data. }\end{array}$ \\
\hline
\end{tabular}

Source: Gamage, 2016

Universities or colleges need to find and use learning methods that improve the most crucial aspects namely human literacy where the main focus is developing the cognitive capacity of students. Therefore they would be able to think critically and systemically. With this humans can function properly especially in connection with "humanity; communication and design. So that learning is centered on the following aspects: 1) Skills in leadership and teamwork. 2) Agility and cultural agility so that students with a variety of backgrounds are able to work in different environments both domestically and in an overseas environment. 3) Entrepreneurship that includes "social entrepreneurship". This means entrepreneurship that is able to contribute to social change sustainability and on target. This basic point must be owned by every student.

The philosophy of the heart (momong), the five senses (among) and understanding (ngemong) put forward the accounting learning process 4.0 creatively, independently, and responsibly towards inspiring accounting according to Pratolo (2015).

Tran \& Phan (2019) in their research stated that the industrial revolution 4.0 and the impact of the industrial revolution 4.0 had an influence on the accounting profession. The achievements of the 4.0 industrial revolution are due to artificial intelligence, cloud computing, and blockchain, which have helped the process of automating data entry, increasing the accuracy and diversity of data 
input and collection. The industrial revolution 4.0 also provides challenges for the accounting profession such as the requirements for information technology skills, adaptation skills, and global language abilities.

Several researchers (Damayanti, 2019) and (Wadan et al., 2019) stated that the existence of a disruptive era changed traditional accounting by encouraging it to become real-time accounting and not only rely on period information because there are more revolutions from high volume data called big data. Big data requires updating information by using complex software. Big Data emerged in the 2000s, where a lot of data could be generated from technological developments along with the intelligence of the Internet of Things (IoT). Big data is very important in the field of accounting and various disciplines. Accountants can use several skills to increase the effectiveness of the company in the following ways: 1) descriptive analysis of big data, to help understand what has happened and what is currently happening in the company. ; 2) diagnostic analysis, to help assess why certain events and outcomes occur; 3) predictive analysis, to help determine what is likely to happen based on the variables; 4) prescriptive analysis, to help determine the best choices that can be made in the event of an incident, 5) Forensic Data Analytics (FDA), which is an analysis of $100 \%$ of data transactions underlying the financial statements for later use by the auditor in predicting fraud, profitability and company going concern; 6) facilitate management and security data; 7) facilitate the alignment of company resources with corporate strategy (Al-abedi \& Ali, 2020), (Daniel, 2015), and (Putritama, 2019) There are three stages needed to get the value of benefits from Big Data (Daniel, 2015), namely: 1) Big data collection, which involves an indication process, sorting data based on data relevance and storing data in a data warehouse; 2) Big data analysis, useful for understanding the information contained in big data; 3) Visualization and application, at this last stage the data has been interpreted and integrated into existing business processes so that it can be used as a guide in decision making. Storage media and security are IT Spending which requires large costs if one has to use server provisioning. Cloud Computing is one alternative to reduce IT Spending costs in terms of data storage and security (Prajanto \& Dian Pratiwi, 2019). Cao et al. (2015) Big data can help the audit process, such as: 1) Identifying and assessing the risks associated with the decision to accept or continue an audit assignment, for example, the risk of bankruptcy or high-level management fraud occurring in the audited entity/company. 2) Identify and test material misstatements that exist in financial statements due to fraud, and test fraud for the risks found. 3) Identifying and assessing the risks of material misstatement through understanding the entity/company being audited and its environment. This includes performing preliminary analytical procedures, and evaluating the design and implementation of internal controls and testing the effectiveness of internal controls. 4) Perform substantive analytical procedures in response to the auditor's assessment of the risks of material misstatement. 5) Performing analytical procedures near the end of the audit process to assist the auditor in determining comprehensive conclusions about whether the financial statements are consistent with the auditor's understanding of the entity/company being audited. 
Internet of Things is a network of physical devices, vehicles, household appliances, and other components embedded with electronic devices, computers, sensors, machines and communications that enable these devices to communicate and share data that are uniquely determined by the computers. It is capable of interacting in today's Internet infrastructure. The concept of the IoT, used to define that Internet is dependent on the data entry by people into the computers according to (Tektüfekçi, 2019). The technological development of Internet of Things has caused better processing power and the ability to save more lots of data. Accountants will be pushed to work faster. This change will have an impact on the work of an accountant (Tata Rini, 2019).

Issa et al., (2016) provided information on various fields related to AI to research in which technology is most expected. In addition, this paper raised methodological and evolutionary questions aimed at transforming AI-driven from auditing the current world into the assurance of the future. The results of the study provided an illustration that the progress of industry 4.0 currently has a very large impact on technological advances used in all activities in the field of accounting. This study discussed how to develop devices with artificial intelligence that can help community activities. This automatically facilitates performance with software that is created but is able to replace humans in their activities. In line with (Issa et al., 2016), (S Kruskopf et al., 2019) amd (Kruskopf et al., 2020) in the research, it was stated that the future work of accountants and auditors is about artificial intelligence to analyze, report and develop the desired output. Even though computers take over the accounting job, the quality of the data is more important because to be able to produce quality data, someone who is able to transfer information is needed and functions as an agent while working to transfer knowledge to the system. This task cannot be done without an expert in the field. (Dirican, 2015) stated that in 2025, approximately $30 \%$ of corporate auditing will be conducted, using maximally unbiased artificial intelligence. The titles of potential future accountants and auditor's job descriptions are presented in the following figure.

\begin{tabular}{ccc} 
Blockchain & Analytics Guru & Historical Accounting \\
Accountant & Analyst \\
\hline Healthcare & Cloud Accounting & Systems Integrator \\
Accountant & Specialist & Strategic Accounting \\
\hline Cybercrime & Fintech City Planner & $\begin{array}{c}\text { Analyst } \\
\text { Accountant }\end{array}$ \\
\hline
\end{tabular}

Fintech Accountant Data Security Accountant

Figure 4. The Titles Of Potential Future Accountants And Auditors Job Descriptions

\section{Source: Kruskopf et al., 2019}

According to Iswanto \& Wahjono (2019), the challenges of the industrial revolution in the 4.0 era can change significantly the overall role and standards of current accountants. Changes in the role of the accountant are: 1) Providing views or opinions regarding data. An accountants are required to be capable of identify questions on the data, statistical analysis, checking data quality and interpreting data processing results. 2) Serving as an advisor, whether as a business advisor, specialist or role as a business partner. 3) Able to work together 
in mastery of technology which includes data manipulation with robots or the like and as a trainer in the field of artificial intelligence. 4) The accounting profession is developing not only in the financial aspect but will also expand to the non-financial reporting aspects and data security in cyberspace (cyber security).

The United States Department of Labor, Bureau of Labor Statistics reported that the accounting profession is projected to grow at a rate of 11 percent over the next 10 years, an increase of more than 142,000 new accounting and auditing jobs. Where are qualifications needed by finance and accounting people are experienced in data analytics, modelling techniques, proficient with accounting software, and proficient in Microsoft Excel (Greenman, 2017).

The greatest impact IT has made on accounting is the company's ability to develop and use computerized systems to track and record financial transactions (Ghasemi et al., 2011). The results of this study illustrate that the performance in terms of accounting systems is getting easier because of the impact of the development of information technology which is growing rapidly so that it makes all accounting activities easier. These technological advances are able to shorten performance so that they can minimize the time needed and can complete a lot of work in a short time.

The application of artificial intelligence technology in the accounting field is an inevitable trend, which will bring about extraordinary changes and developments in the accounting industry (Luo et al., 2018). In this study, by using artificial intelligence applications, the accounting industry as the object of research, analyzes the impact of artificial intelligence on the development of the accounting industry, and puts forward relevant suggestions for existing problems. AI could emerge in all types of operations and services, performance and achievement of automation from buildings to machines, logistical activities to security data and social networks, customer service, research and development, sales, marketing, and informational analysis are constantly measured so that they can optimize work and even make and carry out decisions according to human orders (Greenman, 2017) and (Machkour \& Abriane, 2020).

The BIG Four accounting firm revealed two general trends in the use of AI technology, the first is that many accounting professions are investing in AI and its integration into the core business, and the second is that AI is a key success factor in future accounting (Zhang et al., 2020). Artificial intelligence systems that have been used for calculation and data analysis by audits and companies will change the accounting system and automate accounting and the work of accounting personnel will shift from performing accounting tasks to more creative managerial functions (Osmyatchenko et al., 2019). Human emotional intelligence is incompatible with technology like AI in making important decisions. But accountants need to increase their knowledge of the technology itself because of the advanced technology used in accounting to provide more precise and accurate data to clients (Akhter \& Sultana, 2018).

The new skills required of accountants are the technical expertise in machine learning and the depth of knowledge, investment policy and innovation strategy, communication skills and critical thinking and leadership skill to benefit from the deployment of AI technologies and create more value for the business 
(Association of Chartered Certified Accountants (ACCA), 2016 and (E. Stancheva-Todorova, 2019). Moll \& Yigitbasioglu (2019) also stated that to effectively contribute to organizations that embrace AI, accountants must be vigilant and critical; they need to question the insights and advice provided by this new technology and beware of others who care about the black box way and ignore the inner calculative infrastructure and the plasticity of the resulting value. AI can increase efficiencies, provide greater insight into business processes, and create competitive advantages for adopters. However, there are some ethical concerns with the technology, which, if left unresolved, could negate the anticipated benefits (Munoko \& Vasarhelyi, 2020).

The results of this study illustrated that the development of industrial technology with the development of intelligence has had an impact on the development of the accounting industry. The development that occurred causes all types of work to become easier with the help of intelligence assistance so that the job can be done properly. The application of artificial intelligence technology in accounting is becoming a trend among the economic community so that its development is carried out as well as possible. The role of humans to monitor needs to be improved so that in terms of supervising work it can be done properly. Supervisory workers need good skills so that they can immediately find the slightest error and can immediately find solutions that the system cannot do. This is what needs to be improved so that the human role is always needed, especially the role of the system in work so that human existence is always needed.

The results of this study illustrated that the importance of development in the accounting sector is to keep pace with technological advances in industry 4.0. The development of technology is very important for the advancement of human life so that it continues to develop in a better direction. This must be balanced with the development of knowledge in the field of accounting so that all types of development can be carried out as well as possible. The development of knowledge in the field of accounting can provide the best way to develop a company that must keep up with the progress of industry 4.0. Therefore, it is felt that this needs to be aligned with the development of knowledge when the development of industrial technology 4.0 occurs.

The research that has been done discussed that accounting skills have a great influence in countering the progress of the industrial revolution 4.0. The development of knowledge in accounting can be carried out by providing training and education in accounting so that knowledge and skills can be improved. Due to the rapid development of existing technology, it is very important for the accounting profession to realize that the challenges posed by the development of this technology are opportunities for professional growth and expansion (De Jesus \& Junior, 2020).

In the 4.0 industrial revolution, the accounting profession can take advantage of various information technologies below, creating opportunities and challenges as follows (Association of Chartered Certified Accountants (ACCA), 2013): 1) Accountants and business people are increasingly using artificial intelligence software to automate part of the audit process, and check compliance with financial reporting to international taxes. Opportunities that arise with 
artificial intelligence are automating routine tasks. which is usually done by humans with software-based entities, improving compliance and decision making, increasing service efficiency and effectiveness. The challenge that arises with artificial intelligence is the difficulty in determining when to use professional judgment or rely on artificial intelligence software. The progressive de-skilling of the accounting profession, and artificial intelligence software that is able to learn independently can more effectively answer business problems compared to accountants. 2) Implementing big data can help accountants manage the complexity of the large amounts of data generated. The emerging cloudbased platforms provide access to the on-demand tools needed by organizations and individuals to take advantage of the 'internet of things'. Opportunities that arise with big data include increasing understanding of future planning and the risks that will occur and potentially increasing business effectiveness and lower process costs.

Handoko et al. (2019) to face the challenges of the industrial revolution 4.0, accountants need to do investing in the development of digital skills, curriculum and learning based on human-digital skills (for educational institutions), responsive to changes in the industry, business and technological developments, strategic and analytical skills, to communicate and to be fluent in English with a set of critical thinking, must prepare oneself by honing soft skills both interpersonal skills and intrapersonal skills and being able to adapt to changes that occur, implementing a new technology prototype, and learn by doing

The skill needed for the accounting profession was knowledge of data extraction tools in the mining of business intelligence, use of tools that support data modelling and analysis, knowledge management skills, project management skills, change management skills, knowledge of new approaches to funding and product development, ability to use technology to attract, develop and manage talent, knowledge of emerging payment platforms, better working knowledge of connectivity and IT security, knowledge of how applications integrate (Accountants \& Accountants, 2013).

The industrial revolution 4.0 has a positive impact on the progress of life if it can be balanced properly. Therefore, it is necessary to increase the capacity in accounting. Global economic development requires the improvement and development of capabilities so that each company is able to keep up with these developments properly and can advance company performance. Industry 4.0 is about more than just advanced technologies: It is about the ways in which those technologies are brought together, and how organizations can harness them to drive operations and growth (Cotteleer \& Sniderman, 2017).

The development of industry 4.0 has a very significant impact on the development of people's lives. The community must always follow the flow of development well so that capacity building will continue to be carried out. If this can be conducted well the impact of the development on people's lives will always be a positive impact. 


\section{CONCLUSIONS}

Based on the research conducted, it can be concluded that the emergence of the industrial revolution 4.0 has raised skepticism and optimism. The appearance of various kinds' new technology like artificial intelligence, big data, and Internet of Things had a very significant impact in the development of science and the Accounting profession. Accounting profession jobs that are manual and repetitive in nature has been automated. For example, in the field of auditing, artificial intelligence can make it easier for auditors to review documents should be revisited from a company. It's nothing new if auditors have to examine various types of documents with many pages in them. However, the existence of artificial intelligence can minimize the time spent by auditors in auditing financial statements. Consequently, accountants must accept this technology trend, understand the resulting changes, and seek to know what role they can play in the new economy to be created by the industrial revolution 4.0, like : providing views or opinions regarding data, be able serving as an advisor, whether as a business advisor, specialist or role as a business partner and able to work together in the mastery of technology which includes data manipulation with robots or the like and as a trainer in the field of artificial intelligence. This forced the accounting profession to face various challenges. Improvement and change regulations, as well as learning new techniques related to financial reporting, will have huge impact on the accounting profession in the future. Further research, should be able to discuss the impact of the industrial revolution era 4.0 in more depth. In this study, the sources obtained were still quite minimal, so that the general discussion was not too specific. The discussion can also be linked to other accounting professions, such as internal auditors. Or, it can be related to other matters related to accounting.

\section{REFERECES}

Accountants, A. O. C. C., \& Accountants, I. of M. (2013). Digital Darwinism: Thriving in the face of technology change. Acca, 1-64. http://www.accaglobal.com/content/dam/acca/global/PDFtechnical/futures/pol-afa-tt2.pdf

Akhter, A., \& Sultana, R. (2018). Sustainability of Accounting Profession at the Age of Fourth Industrial Revolution. International Journal of Accounting and Financial Reporting, 8(4), 139. https:// doi.org/10.5296/ijafr.v8i4.13689

Al-abedi, L. T. K., \& Ali, K. (2020). Big Data and Its Accounting Effects between Challenges and Opportunities: A Literature Review L . Hussein Ali Mohaisen. November. https://doi.org/10.31272/JAE.43.2020.124.A7

Association of Chartered Certified Accountants (ACCA). (2013). Technology trends: Their impact on the global accountancy profession. Acca, 1-16. www.accaglobal.com/futures\%0Ahttp://www.accaglobal.com/content/da m/acca/global/PDF-technical/futures/pol-af-ttti.pdf

Association of Chartered Certified Accountants (ACCA). (2016). The Future of Audit. CFA Institute Magazine, 27(3), 55-55. https://doi.org/10.2469/cfm.v27.n3.18

Burritt, R., \& Christ, K. (2016a). Industry 4.0 and environmental accounting: a new revolution? Asian Journal of Sustainability and Social Responsibility, 1(1), 
23-38. https:/ / doi.org/10.1186/s41180-016-0007-y

Burritt, R., \& Christ, K. (2016b). Industry 4.0 and environmental accounting: a new revolution? Asian Journal of Sustainability and Social Responsibility, 1(1), 23-38. https:// doi.org/10.1186/s41180-016-0007-y

Cotteleer, M., \& Sniderman, B. (2017). Forces of change: Industry 4.0. Deloitte Insights, 1-20. https://doi.org/10.1007/ s11947-009-0181-3

Damayanti, C. R. (2019). Accounting and Its Challenges in the New Era. 93(AICoBPA 2018), 81-83. https://doi.org/10.2991/aicobpa-18.2019.19

Daniel, B. (2015). Big Data and analytics in higher education: Opportunities and challenges. British Journal of Educational Technology, 46(5), 904-920. https://doi.org/10.1111/bjet.12230

De Jesus, S. M. S., Freire Campos, J., \& De Oliveira Junior, A. M. (2020). the Technological Revolution and the New Profile of the Accounting Professional With the Entry of Digital Innovation. International Journal for Innovation Education and Research, 8(2), 221-229. https://doi.org/10.31686/ijier.vol8.iss2.2200

Dirican, C. (2015). The Impacts of Robotics, Artificial Intelligence On Business and Economics. Procedia - Social and Behavioral Sciences, 195, 564-573. https://doi.org/10.1016/j.sbspro.2015.06.134

Gamage, P. (2016). Big Data: are accounting educators ready? Journal of Accounting and Management Information Systems, 15(3), 588-604.

Ghasemi, M., Shafeiepour, V., Aslani, M., \& Barvayeh, E. (2011). The impact of information technology (it) on modern accounting systems. Procedia - Social and Behavioral Sciences, 28, 112-116. https://doi.org/10.1016/j.sbspro.2011.11.023

Greenman, C. (2017). Exploring the Impact of Artificial Intelligence on the Accounting Profession. Journal of Research in Business, Economics and Management, $8(3)$, 1451-1454. www.scitecresearch.com/journals/index.php/jrbem/index\%0Awww.scitec research.com

Halmi. (2018). Improvement Of Accountant Professional Capacity In Facing The Era Of Industrial Revolution 4.0 By Revitalizing Accounting Curriculum Through Integrating Information Technology. Era, Menghadapi Industri, Revolusi, 199-205.

Handoko, B. L., Mulyawan, A. N., Samuel, J., Rianty, K. K., \& Gunawan, S. (2019). Facing industry revolution 4.0 for millennial accountants. International Journal of Innovative Technology and Exploring Engineering, 9(1), 1037-1042. https://doi.org/10.35940/ijitee.A4681.119119

Issa, H., Sun, T., \& Vasarhelyi, M. A. (2016). Research ideas for artificial intelligence in auditing: The formalization of audit and workforce supplementation. Journal of Emerging Technologies in Accounting, 13(2), 1-20. https://doi.org/10.2308/jeta-10511

Iswanto, A. C., \& Wahjono. (2019). Pengaruh Revolusi Industri 4.0 Terhadap Ilmu Akuntansi. Jurna Ilmiah INFOKAM, 1(1), 1-6.

Khanh, lam T. (2018). Impact Of Industrial Revolution 4.0 (Industry 4.0) To The Accounting Profession In Vietnam (Issue September). https://www.researchgate.net/publication/327933242 
Kruskopf, S, Lobbas, C., Meinander, H., \& Söderling, K. (2019). Digital Accounting: Opportunities, Threats and the Human Factor. ACRN Oxford Journal of Finance and Risk Perspectives, 8, 1-15.

Kruskopf, Shawnie, Lobbas, C., Meinander, H., Söderling, K., Martikainen, M., \& Lehner, O. (2020). Digital Accounting and the Human Factor: Theory and Practice. ACRN Journal of Finance and Risk Perspectives, 9(1), 78-89. https:// doi.org/10.35944/jofrp.2020.9.1.006

Luo, J., Meng, Q., \& Cai, Y. (2018). Analysis of the Impact of Artificial Intelligence Application on the Development of Accounting Industry. Open Journal of Business and Management, 06(04), 850-856. https://doi.org/10.4236/ojbm.2018.64063

Machkour, B., \& Abriane, A. (2020). ScienceDirect ScienceDirect its Implications its Implications the Financial Sector. Procedia Computer Science, 177, 496-502. https://doi.org/10.1016/j.procs.2020.10.068

Min Cao; Roman Chychyla; Trevor Stewart. (2015). Big Data Analytics in Financial Statement Audits. Accounting Horizons, 29(2), 423-429. https://doi.org/10.2308/acch-51068

Moll, J., \& Yigitbasioglu, O. (2019). The role of internet-related technologies in shaping the work of accountants: New directions for accounting research. British Accounting Review, 51(6), 100833. https://doi.org/10.1016/j.bar.2019.04.002

Munoko, I., Brown-Liburd, H. L., \& Vasarhelyi, M. (2020). The Ethical Implications of Using Artificial Intelligence in Auditing. Journal of Business Ethics, 167(2), 209-234. https://doi.org/10.1007/s10551-019-04407-1

Osmyatchenko, Volodymyr, Viktoriia Oliinyk, Olexandra Mazina , Natalia Matselyukh, Valerii Ilin, A. O. (2019). Journal of Security and Sustainability Issues "The Influence Of The Global Technological Changes On Principles And Functions Of Accounting And Formation Of The Organization Strategy," 8(4), 89. https://doi.org/10.1111/j.1745-6584.2009.00625_2.x

Perry, A., \& Hammond, N. (2002). Systematic Reviews: The Experiences of a PhD Student. Psychology Learning \& Teaching, 2(1), 32-35. https://doi.org/10.2304/plat.2002.2.1.32

Prajanto, A. P., \& Dian Pratiwi, R. (2019). p-ISSN 2526-4440 e-ISSN 2086-3748. Industrial Revolution 4.0: Design of Financial Accounting System and Transaction Development, 10(1), 133-148.

Pratolo, S. (2015). Information Technology and the Role of Management Accountants, a Strategic Management Supporter in Achieving Competitive Advantage. Journal of Accounting and Investment, 1(2), 68-76. https://doi.org/10.1017/CBO9781107415324.004

Putritama, A. (2019). Peluang Dan Tantangan Untuk Manajemen Akuntansi Di Era Big Data. Jurnal Ekonomi Manajemen Sistem Informasi, 1(1), 33-39. https://doi.org/10.31933/jemsi.v1i1.44

Stancheva-Todorova, A. (2019). Are Accounting Educators Ready to Embrace the Challenges of Industry 4.0. International Scientific Journal "Industry 4.0," 4(6), 309-312. http:/ / www.accaglobal.com/bigdata

Surianti, M. (2020). Development of Accounting Curriculum Model Based on Industrial Revolution Approach. Research Journal of Finance and Accounting, 
11(2), 116-123. https:// doi.org/10.7176/rjfa/11-2-12

Tata Rini, Y. (2019). Parsing the Accounting Roadmap for the Industrial Age 4.0. Journal of Management and Accounting Sciences, 7(1), 58. https://doi.org/10.33366/ref.v7i1.1339

Tektüfekçi, F. (2019). A Bibliometric Analysis of Industry 4.0-Focused Turkish EAccounting Applications. Procedia Computer Science, 158, 602-608. https://doi.org/10.1016/j.procs.2019.09.094

Tran \& Phan. (2019). Impact of Industrial Revolution 4.0 to the Accounting Industry in Vietnam. 5.

Wadan, R., Teuteberg, F., Bensberg, F., \& Buscher, G. (2019). Understanding the Changing Role of the Management Accountant in the Age of Industry 4.0 in Germany. Proceedings of the 52nd Hawaii International Conference on System Sciences, 5817-5826. https:/ / doi.org/10.24251/hicss.2019.702

Wahyuni, T. (2020). The Role of Information Technology in Supporting Accountant Profession in the Era of Industrial Revolution 4.0. 426(Icvhe 2018), 256-264. https://doi.org/10.2991/assehr.k.200331.150

Zhang, Y., Xiong, F., Xie, Y., Fan, X., \& Gu, H. (2020). The Impact of Artificial Intelligence and Blockchain on the Accounting Profession. IEEE Access, 8, 110461-110477. https:// doi.org/10.1109/ACCESS.2020.3000505 